\title{
STRATEGI FLIPPED CLASSROOM UNTUK MENINGKATKAN KEMAMPUAN BERBICARA MELALUI STUDENT'S MINIMOVIE PROJECT
}

\author{
Dian Maya Kurnia ${ }^{1}$, Reky Lidyawaty ${ }^{2}$ \\ aroundmaya86@gmail.com¹, RekyLidyawaty@gmail.com² \\ Fakultas Sastra, Abdurachman Saleh University Indonesia ${ }^{1}$, \\ FKIP, Abdurachman Saleh University Indonesia ${ }^{2}$
}

\begin{abstract}
Abstrak
Salah satu yang mempengaruhi keberhasilan mata kuliah speaking adalah keaktifan mahasiswa dalam berpartipasi dalam kegiatan pembelajaran di kelas. Namun dalam kenyataannya, mahasiswa tidak dapat berlatih berbicara secara maksimal dikarenakan waktu perkuliahan yang pendek. Mahasiswa jarang sekali belajar di rumah dan mempraktekan komunikasi dalam berbahasa Inggris diluar kelas. Fakta yang terjadi lapangan adalah $65 \%$ mahasiswa tidak tuntas dalam mata kuliah speaking. Desain penelitian yang digunakan dalam penelitian ini adalah desain Penelitian Tindakan Kelas (PTK). Dari hasil analisis dalam penelitian dan pembahasan yang telah diperoleh melalui penerapan metode flipped classroom dalam pembelajaran berbicara bahasa Inggris pada mahasiswa semester IV Jurusan Bahasa Inggris Universitas Abdurachman Saleh, dapat disimpulkan bahwa dari data yang telah dianalisis diperoleh nilai mahasiswa dalam kegiatan Speaking di kelas untuk ketepatan (accuracy), pada siklus ke satu adalah 2.75, siklus kedua sebesar 3.31 dan siklus ketiga 3.92. Nilai mahasiswa untuk kelancaran berbahasa ( fluency) pada siklus ke satu adalah 2.75, siklus kedua sebesar 3.31 dan siklus ketiga 3.92, sedangkan nilai mahasiswa dalam kegiatan Speaking di kelas untuk kesesuaian makna ( comprehension), pada siklus ke satu adalah 2.41, siklus kedua sebesar 2.68 dan siklus ketiga 3.82. Sedangkan persentase ketercapaian ketuntasan juga semakin meningkat pada setiap siklus, dimana pada siklus I sebesar $30 \%$, siklus II sebesar 57,5\%, dan siklus III sebesar 87,5\%. Kesimpulan penelitian ini adalah kinerja mahasiswa dalam proses pembelajaran Speaking English dengan menggunakan metode flipped classroom semakin baik pada tiap siklusnya. Hal ini ditunjukkan dengan semakin meningkatnya score mahasiswa dari siklus I sampai siklus III.

Kata Kunci : Flipped Classroom, Kemampuan Berbicara, Students' inimovie project
\end{abstract}

\section{PENDAHULUAN}

Pembelajaran merupakan salah satu kunci utama dalam mencapai tujuan pendidikan. Pembelajaran yang baik adalah pembelajaran yang berlangsung secara efektif dan efisien sehingga dapat mencapai suatu tujuan. Pembelajaran menurut Gintings (2008: 34) adalah pengalaman terencana yang membawa perubahan tingkah laku, memotivasi dan menyediakan fasilitas agar terjadi proses belajar pada diri peserta didik. Pembelajaran memiliki dua karakteristik 
yaitu Pertama, dalam proses pembelajaran melibatkan proses mental mahasiswa secara maksimal bukan hanya sekedar mendengar, mencatat, akan tetapi menghendaki aktivitas mahasiswa dalam proses berpikir. Kedua, dalam pembelajaran membangun suasana dialogis dan proses tanya jawab terusmenerus yang diarahkan untuk memperbaiki dan meningkatkan kemampuan berpikir mahasiswa.

Proses pembelajaran pada setiap satuan pendidikan tinggi harus interaktif, inspiratif, menyenangkan, menantang, dan memotivasi peserta didik untuk berpartisipasi aktif serta memberikan ruang yang cukup bagi prakarsa, kreativitas dan kemandirian sesuai dengan bakat, minat, dan perkembangan fisik serta psikologis peserta didik (Permendiknas RI No. 41, 2007: 6). Apabila dicermati apa yang dikemukakan dalam Permen tersebut menunjukkan bahwa peran aktif mahasiswa dalam pembelajaran merupakan suatu keharusan. Hal ini menunjukkan bahwa mengajar yang didesain dosen harus berorientasi pada hasil belajar mahasiswa.

Perilaku pembelajaran yang diharapkan seharusnya adalah sebagai berikut: (1) pemberian informasi, perintah, dan pertanyaan oleh dosen mestinya hanya sekitar 10 sampai dengan $30 \%$, selebihnya sebaiknya berasal dari mahasiswa, (2) mahasiswa mencari informasi, mencari dan memilih serta menggunakan sumber informasi, (3) mahasiswa mengambil inisiatif lebih banyak, (4) mahasiswa mengajukan pertanyaan, (5) mahasiswa berpartisipasi dalam proses perencanaan, pelaksanaan, dan evaluasi pembelajaran, (6) ada penilaian diri dan ada penilaian sejawat.

Salah satu yang mempengaruhi keberhasilan mata kuliah speaking adalah keaktifan mahasiswa dalam berpartipasi dalam kegiatan pembelajaran di kelas. Namun dalam kenyataannya, mahasiswa tidak dapat berlatih berbicara secara maksimal dikarenakan waktu perkuliahan yang pendek. Mahasiswa jarang sekali belajar di rumah dan mempraktekan komunikasi dalam berbahasa Inggris diluar kelas. Fakta yang terjadi lapangan adalah $65 \%$ mahasiswa tidak tuntas dalam mata kuliah speaking. Mahasiswa merasa kesulitan Dalam proses belajar aktif 
mahasiswa dilibatkan dalam proses belajar mengajar, tidak hanya dosen menyampaikan ilmu pengetahuan yang dimiliki dosen kepada mahasiswa tetapi mahasiswa mendapat pengetahuan dengan keterlibatan mereka secara aktif dalam kegiatan pembelajaran. Keaktifan mahasiswa dalam mengikuti proses belajar mengajar dapat dilihat, yakni (1) Keinginan, keberanian menampilkan minat, kebutuhan, permasalahannya, (2) Keinginan serta keberanian serta kesempatan untuk berpartisipasi dalam kegiatan persiapan, proses dan kelanjutan belajar, (3) Penampilan berbagai usaha/keaktifan belajar dalam menjalani dan menyelesaikan kegiatan belajar mengajar sampai mencapai keberhasilan, (4) Kebebasan/keleluasaan melakukan hal tersebut tanpa tekanan dosen/pihak lainnya (kemandirian diri).

Suatu strategi yang bisa digunakan sebagai acuan dosen dalam peningkatan keaktifan belajar serta kemampuan berbicara mahasiswa, yaitu strategi flipped classroom. Flipped classroom merupakan strategi yang dapat diberikan oleh pendidik dengan cara meminimalkan jumlah instruksi langsung dalam praktek mengajar mereka sambil memaksimalkan interaksi satu sama lain. Strategi ini memanfaatkan teknologi yang menyediakan tambahan yang mendukung materi pembelajaran bagi mahasiswa yang dapat diakses secara online. Hal ini membebaskan waktu kelas yang sebelumnya telah digunakan untuk pembelajaran.

Dengan strategi flipped classroom mahasiswa mendapat pembelajaran tidak hanya didalam kelas saja namun diluar kelas mahasiswa juga dapat mengakses atau melihat materi yang diberikan oleh dosen secara berulang-ulang dengan bantuan internet atau video pembelajaran yang diberikan oleh dosen. Tahapan pembelajaran dengan flipped classroom pada mahasiswa yaitu mempelajari topik sendiri, biasanya menggunakan pelajaran video yang dibuat oleh instruktur atau bersama oleh pendidik lain. Di dalam kelas, mahasiswa kemudian mencoba untuk menerapkan pengetahuan dengan memecahkan masalah dan melakukan kerja praktek salah satunya dengan pembelajaran berkelompok. Peran dosen di kelas ini bukan untuk memberikan pelajaran awal, sehingga dosen dapat menghabiskan lebih banyak waktu berinteraksi dengan mahasiswa. Hal ini memungkinkan waktu 
di dalam kelas yang akan digunakan untuk kegiatan pembelajaran berbasis tambahan, termasuk penggunaan instruksi dibedakan dan pembelajaran berbasis proyek.

Berdasarkan uraian diatas peneliti merasa perlu untuk menerapkan strategi flipped classroom dalam mata kuliah Speaking melalui untuk students' minimovie project untuk mengetahui pengaruh dari strategi flipped classroom terhadap kemampuan psychomotoric ditinjau dari seberapa besar keaktifan belajar mahasiswa.

Pembelajaran menggunakan model Flipped Classroom memiliki keterkaitan dengan taksonomi Bloom. Taksonomi Bloom pada ranah kognitif memiliki enam kategori dari paling rendah ke tinggi yaitu pengetahuan, pemahaman, penerapan, analisa, sintesis, dan evaluasi. Menurut Brame (2013), pada pembelajaran konvensional kategori pengetahuan dan pemahaman berlangsung di dalam kelas sedangkan kategori penerapan, analisa, evaluasi, dan mencipta dicapai melalui pekerjaan rumah. Tujuan tersebut tidak mudah tercapai karena mahasiswa akan terhenti jika menemui hambatan dalam mengerjakan pekerjaan rumah. Pada pembelajaran Flipped Classroom, kategori pengetahuan dan pemahaman diperoleh di rumah melalui video pembelajaran yang diberikan oleh dosen sedangkan kategori penerapan, analisa, evaluasi, dan mencipta berlangsung di dalam kelas saat pembelajaran berlangsung. Pada taksonomi Bloom ranah kognitif, menurut Utari (2013) tingkatan pengetahuan, pemahaman, dan penerapan merupakan Lower Order Thinking Skills, sedangkan tingkatan analisa, evaluasi, dan mencipta merupakan Higher Order Thinking Skills. Kemampuan pemecahan masalah merupakan salah satu kemampuan mahasiswakategori Higher Order Thinking Skills (Forster, 2004). Model Flipped Classroom terbagi dalam beberapa tipe, beberapa di antaranya adalah Traditional Flipped Classroom dan Peer Instruction Flipped (Steele, 2013). Model pembelajaran Traditional Flipped sering digunakan oleh dosen yang belum pernah menggunakan model Flipped Classroom sebelumnya. Pada model pembelajaran Traditional Flipped mahasiswa diminta untuk menonton video 
pembelajaran atau media lainnya di rumah pada pembelajaran sebelumnya. Mahasiswa mempersiapkan diri untuk mengikuti pembelajaran di kelas dengan belajar terlebih dahulu di rumah. Langkah selanjutnya adalah mahasiswa datang ke kelas untuk melakukankegiatan dan mengerjakan tugas yang berkaitan. Di kelas mahasiswa menerapkan kemampuan dalam proyek ataupun simulasi lainnya. Kegiatan yang berlangsung dikelas dipandu mengunakan lembar kerja mahasiswa. Tugas yang berkaitan juga diberikan dengan dalam lembar kerja mahasiswa. Kegiatan selanjutnya adalah mengukur pemahaman mahasiswa dengan mengadakan kuis diakhir pembelajaran.

\section{METODE PENELITIAN}

Penelitian yang digunakan dalam penelitian ini adalah desain Penelitian Tindakan Kelas (PTK). Menurut Kemmis \& Carr (dalam Kasbolah \& Sukaryana, 2006:9) menyatakan bahwa Penelitian Tindakan Kelas (PTK) adalah suatu bentuk penelitian yang bersifat reflektif yang dilakukan oleh pelaku dalam masyarakat sosial dan bertujuan untuk memperbaiki pekerjaannya, memahami pekerjaan serta situasi tempat pekerjaan itu dilakukan.

Desain penelitian yang digunakan dalam penelitian ini adalah model skema Kemmis dan Mc Taggart. Dalam perencanaan Kemmis menggunakan sistem spiral refleksi diri yang dimulai dengan perencanaan, tindakan, pengamatan (observasi), dan refleksi (Kasbolah \& Sukaryana, 2006:63). Keempat fase tersebut merupakan suatu siklus dalam sebuah penelitian tindakan kelas. 


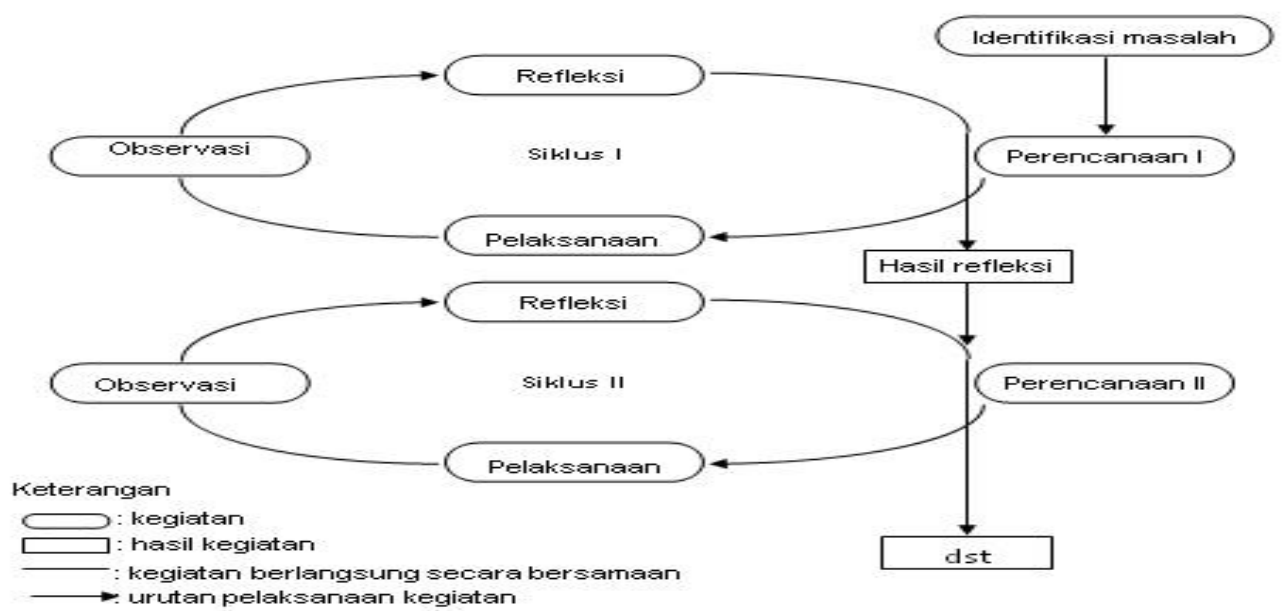

Gambar 1. Bagan Penelitian Tindakan Model Spiral

\section{Langkah-Langkah Penerapan Metode Fipped Classroom Dalam Pembelajaran Speaking English Dengan Model Kemmis\&McTaggart (Model Siklus)}

berdasarkan gambar model tersebut ada beberapa langkah dalam penelitian tindakan kelas, yaitu:

Pada hasil penelitian ini, peneliti mendeskripsikan langkah-langkah penerapan metode flipped classroom dalam pembelajaran Speaking English dengan model Kemmis\&McTaggart (model siklus) yang dilakukan dalam tiga siklus dan tiap-tiap siklusnya mempunyai alokasi waktu 2 x 50 menit. Setiap siklus mencakup 4 tahapan, yaitu: Perencanaan (Planning), Tindakan (Acting), Pengamatan (Observing), dan Refleksi (Reflecting) sebagai berikut:

\section{a. Siklus ke-1}

\section{Rencana Penelitian}

Pada tahap ini peneliti mempersiapkan semua perlengkapan yang diperlukan selama kegiatan belajar mengajar Speaking English dengan menggunakan metode flipped classroom. Perlengkapan tersebut terdiri dari Rencana Pelaksanaan Pembelajaran (RPP), minimovie video, lembar observasi, lembar evaluasi, dan alat-alat yang digunakan dalam pembelajaran Speaking English. Adapun indikator yang ingin dicapai adalah Mahasiswa dapat 
mendeskripsikan tentang lokasi objek wisata (describe about tourism object ) yang meliputi deskripsi tentang indentitas tempat pariwisata seperti: karakteristik tempat wisata, lokasi, jenis transportasi yang digunakan untuk menuju tempat wisata, harga tiket, keunggulan wisata yang ditawarkan, dengan menggunakan bahasa Inggris yang benar dan lancar sesuai dengan topik yang telah ditentukan oleh dosennya, yaitu tentang "tourism object".

\section{Tahap pelaksanaan ( act)}

Dosen bertanggung jawab pada pelaksanaan. Dalam penelitian ini peneliti melibatkan rekan sejawat sebagai observer yaitu Bapak Heldie Bramantyo dan Ibu Nur Kholifatus Zuhro untuk mengamati segala aktifitas peneliti pada saat

menerapkan metode flipped classroom. Pembelajaran yang disusun adalah tiga kali pertemuan. Adapun beberapa kegiatan yang akan dilakukan dosen sebagai berikut

\section{Pendahuluan}

Kegiatan ini diawali dengan mengumpulkan tujuan pembelajaran dan memotivasi mahasiswa. Motivasi ini dilakukan dengan memberikan pertanyaan tentang tourism object. Kegiatan ini merupakan salah satu bentuk kegiatan “warming-up" yang diberikan oleh dosen Speaking English kepada mahasiswa di dalam kelas sebelum materi Speaking English dimulai.

\section{Kegiatan Inti}

Dalam kegiatan inti Flipped Classroom diterapkan kepada mahasiswa. Langkah langkah pembelajaran menggunakan Flipped Classroom sebagai berikut:

1. Kegiatan pembelajaran dilaksanakan dalam kelompok yang terbagi dalam 8 kelompok dengan masing-masing kelompok terdiri dari 5 mahasiswa yang bersifat heterogen. Pembentukan kelompok ini dilakukan sebelum proses belajar mengajar berlangsung.

2. Sebelum tatap muka, mahasiswa diminta untuk belajar mandiri di rumah mengenai materi untuk pertemuan berikutnya, dengan menonton video 
pariwisata. Dalam kegiatan awal akan disampaikan apersepsi, motivasi, dan tujuan pembelajaran.

3. Peran dosen pada saat kegiatan belajar berlangsung adalah memfasilitasi berlangsungnya Di samping itu, dosen juga akan menyiapkan beberapa pertanyaan (soal) dari materi tersebut.

4. Dosen menyiapkan beberapa pertanyaan tentang taman nasional Baluran.Dosen meminta mahasiswa untuk berdiskusi menjawab pertanyaan mengenai kondisi taman nasional baluran, cara mempromosikan objek pariwisata, keunggulan wisata yang ditawarkan.

5. Pembelajaran dilanjutkan dengan presentasi perwakilan dari masingmasing kelompok untuk memaparkan hasil diskusi dalam matakuliah Speaking English.

6. Dosen memberikan evaluasi berupa tes Speaking English kepada setiap anggota kelompok untuk mengetahui pemahaman mahasiswa terhadap materi yang telah disampaikan.

7. Dosen membimbing mahasiswa menyimpulkan hasil pembelajaran yang telah dilakukan.

8. Dosen memberikan penghargaan untuk kelompok terbaik dan mahasiswa teraktif dalam kelas.

\section{Observasi}

Selama kegiatan pembelajaran, peneliti mengamati proses pembelajaran Speaking English. Analisa pengamatan pengelolaan pengajaran Speaking English tiap-tiap siklus dinilai oleh dua orang observer yaitu Observer I ( Heldie Bramantyo ) dan pengamat II (Nur Kholifatus Zuhro) kemudian dirata-rata nilai dari kedua pengamat tersebut. Hasil rerata nilai pengelolaan pengajaran Speaking English pada pertemuan pertama sebesar 1,90 dengan kategori cukup.

\section{Refleksi}

Setelah tahap kegiatan dan pengamatan, diperoleh gambaran tentang kekurangan yang terjadi pada siklus I sebagai berikut: 
a. Mahasiswa kurang memberikan respon positif selama proses pembelajaran, banyak mahasiswa yang masih menggunakan Bahasa Indonesia dikombinasikan dengan Bahasa Inggris untuk menjelaskan tentang objek wisata.

b. Sebagian besar mahasiswa menggunakan kata penghubung "mmm" dan “eee" apabila lupa atau tidak memahami kosakata dalam bahasa Inggris

c. Mahasiswa malu ketika presentasi di depan kelas

d. Mahasiswa kurang antusias, karena banyak mahasiswa yang bergurau selama pembelajaran Speaking English sehingga kondisi kelas agak ramai. Berdasarkan dari hasil refleksi pada siklus ke-I, peneliti menemukan banyak kekurangan-kekurangan yang terjadi pada siklus pertama di atas yang nantinya akan dijadikan masukan untuk diperbaiki dalam pembelajaran Speaking English pada siklus II yaitu:

a. Memberikan motivasi agar mahasiswa lebih berminat dalam mengikuti pembelajaran Speaking English dan memberikan kosakata yang berkaitan dengan pariwisata sebelum pembelajaran berlangsung.

b. Memberikan bimbingan yang lebih baik pada kelompok yang kesulitan dalam melakukan latihan berbicara bahasa Inggris.

c. Membimbing dengan lebih baik kepada perwakilan dari masing-masing kelompok yang mempresentasikan tourism object.

d. Dosen harus lebih bisa menguasai kelas dengan memberikan nasihat dan peringatan kepada mahasiswa yang tidak serius selama proses pembelajaran berlangsung dan meminta mahasiswa tersebut tidak mengulanginya lagi sehingga suasana kelas menjadi kondusif.

\section{b. Siklus Kedua}

\section{Rencana Penelitian}

Pada siklus kedua ini rancangan dilakukan berdasarkan pada revisi putaran pertama. Ada beberapa hal yang perlu diperbaiki adalah:

a. Kemampuan mahasiswa dalam berkomunikasi dan presentasi menggunakan Bahasa Inggris 
b. Kemampuan dosen membimbing mahasiswa yang mengalami kesulitan dalam berbicara bahasa Inggris.

c. Kemampuan dosen dalam membimbing mahasiswa untuk mempresentasikan pengalamannya selama mengikuti proses pembelajaran Speaking English.

d. Kemampuan dosen dalam menguasai kelas.

Sebelum melakukan proses belajar mengajar, ada beberapa hal yang harus dipersiapkan diantaranya materi yang akan diajarkan dengan topik di (tourism and culture), RPP, lembar evaluasi mahasiswa, lembar penilaiam

\section{Pelaksanaan Tindakan}

1. Pada awal pembelajaran dosen mengadakan reinforcement mengenai video yang diamati oleh mahasiswa di rumah mengenai tourism and culture. Dosen menanyakan tentang tourism object yang sering mahasiswa kunjungi dan kebudayaan apa saja yang terdapat terdapat di Kabupaten Situbondo.

2. Kegiatan pembelajaran dilaksanakan dalam kelompok yang terbagi dalam 8 kelompok dengan masing-masing kelompok terdiri dari 5 mahasiswa.

3. Dosen meminta setiap kelompok membuat video mengenai tourism object

4. Peran dosen pada saat kegiatan belajar berlangsung adalah memfasilitasi berlangsungnya proses pembelajaran. Dosen juga menyiapkan kosakata yang berhubungan dengan video yang telah dibuat oleh mahasiswa. Di samping itu, dosen juga akan menyiapkan beberapa pertanyaan (soal) dari materi tersebut.

5. Dosen menyiapkan beberapa pertanyaan tentang tempat wisata dan kebudayaan di Kabupaten Situbondo. Dosen meminta mahasiswa untuk berdiskusi menjawab pertanyaan mengenai kondisi taman nasional baluran, cara mempromosikan objek pariwisata, keunggulan wisata yang ditawarkan, 
6. Pembelajaran dilanjutkan dengan presentasi perwakilan dari masingmasing kelompok untuk memaparkan hasil diskusi dalam matakuliah Speaking English.

7. Dosen memberikan evaluasi berupa tes Speaking English kepada setiap anggota kelompok untuk mengetahui pemahaman mahasiswa terhadap materi yang telah disampaikan.

8. Dosen membimbing mahasiswa menyimpulkan hasil pembelajaran yang telah dilakukan.

9. Dosen memberikan penghargaan untuk kelompok terbaik dan mahasiswa teraktif dalam kelas.

\section{Observasi}

Selama kegiatan belajar mengajar berlangsung, observer mengamati proses jalannya pembelajaran dengan menggunakan metode flipped classroom dilakukan oleh dosen Speaking English. Hasil hasil rata-rata penilaian lembar pengamatan pengelolaan pengajaran Speaking English pada siklus kedua sebesar 2,73 dengan kategori sedang

\section{Refleksi}

Setelah tahap pengamatan pada siklus II diperoleh gambaran sebagai berikut:

Dosen sudah dapat memberikan motivasi dengan baik sehingga mahasiswa lebih berminat dalam mengikuti pembelajaran.

a. Mahasiswa masih kesulitan dalam melaksanakan presentasi

b. Dosen sudah lebih baik dalam menguasai kelas walaupun masih ada mahasiswa yang bergurau dan tidak serius selama pembelajaran Speaking English berlangsung di dalam kelas.

Berdasarkan dari hasil refleksi pada siklus ke-II, peneliti masih menemukan adanya kekurangan-kekurangan yang terjadi pada siklus kedua diatas yang nantinya akan dijadikan masukan untuk diperbaiki dalam pembelajaran Speaking English pada siklus ke-III yaitu:

1.Dosen lebih baik lagi dalam membimbing kelompok yang melakukan presentasi. 
2. Dosen berusaha lebih keras menegur mahasiswa yang sering bergurau dan tidak serius selama proses pembelajaran Speaking English di dalam kelas bahkan jika diperlukan memberikan sangsi agar tidak mengulangi lagi.

\section{c. Siklus Ketiga}

\section{Rencana Penelitian}

Pada siklus ketiga ini, rancangan dilakukan berdasarkan revisi pada siklus kedua. Hal yang perlu diperbaiki adalah kemampuan dosen dalam membimbing mahasiswa dalam proses pembelajaran Speaking dan penanganan terhadap mahasiswa yang melakukan tindakan menyimpang atau melanggar. Sebelum melaksanakan proses belajar mengajar, ada beberapa hal yang harus dipersiapkan diantaranya materi yang akan diajarkan dengan topik Situbondo traditional culinary, RPP, Evaluasi mahasiswa, lembar pengamatan, alat dan bahan yang akan digunakan dalam pembelajaran Speaking.

\section{PelaksanaanTindakan}

Pada awal pembelajaran dosen memotivasi mahasiswa. Motivasi ini dilakukan dengan memberikan persepsi tentang traditional culinary dengan cara menampilkan video tentang berbagai makanan tradisional Situbondo baik dengan menggunakan laptop dan slide/LCD proyektor di dalam kelas. Kegiatan ini merupakan salah satu bentuk kegiatan "warming-up” yang diberikan oleh dosen Speaking English kepada mahasiswa di dalam kelas sebelum materi Speaking English dimulai.

1. Dosen menyampaikan tujuan pembelajaran

2. Pada awal pembelajaran dosen mengadakan reinforcement mengenai video yang diamati oleh mahasiswa di rumah mengenai traditional culinary. Dosen menanyakan tentang makanan yang tradisional yang terdapat terdapat di Kabupaten Situbondo.

3. Kegiatan pembelajaran dilaksanakan dalam kelompok yang terbagi dalam 8 kelompok dengan masing-masing kelompok terdiri dari 5 mahasiswa. 
4. Dosen meminta setiap kelompok membuat video mengenai local food ( traditional culinary).

5. Peran dosen pada saat kegiatan belajar berlangsung adalah memfasilitasi berlangsungnya proses pembelajaran. Dosen juga menyiapkan kosakata yang berhubungan dengan video yang telah dibuat oleh mahasiswa. Di samping itu, dosen juga akan menyiapkan beberapa pertanyaan (soal) dari materi tersebut.

6. Dosen menyiapkan beberapa pertanyaan tentang produk lokal di Kabupaten Situbondo. Dosen meminta mahasiswa untuk berdiskusi menjawab pertanyaan mengenai potensi lokal daerah.

7. Pembelajaran dilanjutkan dengan presentasi perwakilan dari masing-masing kelompok untuk memaparkan hasil diskusi dalam matakuliah Speaking English.

8. Dosen memberikan evaluasi berupa tes Speaking English kepada setiap anggota kelompok untuk mengetahui pemahaman mahasiswa terhadap materi yang telah disampaikan.

9. Dosen membimbing mahasiswa menyimpulkan hasil pembelajaran yang telah dilakukan.

10. Dosen memberikan penghargaan untuk kelompok terbaik dan mahasiswa teraktif dalam kelas.

\section{Observasi}

Selama kegiatan belajar mengajar berlangsung, peneliti mengamati proses jalannya penerapan model pembelajaran Speaking English dengan menggunakan metode flipped classroom yang dilakukan oleh dosen Speaking English. Hasil ratarata penilaian lembar pengamatan pengelolaan pengajaran Speaking English pada siklus ketiga sebesar 3,67 dengan kategori sangat baik.

\section{Refleksi}

Setelah tahap kegiatan dan pengamatan pada siklus III diperoleh gambaran sebagai berikut: 
a. Dosen sudah membimbing mahasiswa dengan baik dalam proses pembelajaran matakuliah Speaking English dengan menggunakan metode flipped classroom.

b. Presentasi kelompok sudah berjalan dengan baik.

c. Penanganan mahasiswa yang tidak serius mengikuti pembelajaran Speaking

English sudah baik dibuktikan dengan kondisi mahasiswa yang sudah kondusif dan mahasiswa antusias dalam mengikuti pembelajaran.

Pada siklus ke-III ini pelaksanaan pembelajaran Speaking English yang dilakukan oleh dosen dengan menggunakan metode getting information game berjalan dengan baik, sehingga semua kekurangan pada siklus pertama dan kedua dapat teratas. Namun dosen masih perlu meningkatkan kegiatan percobaan secara efektif dan tepat waktu terutama agar kemampuan psikomotorik mahasiswa meningkat serta hasil yang dicapai akan menjadi lebih baik. Revisi ini digunakan untuk pembelajaran Speaking English selanjutnya jika dilakukan dengan metode yang sama. Rata-rata penilaian pengelolaan pembelajaran Speaking English dari siklus pertama sampai siklus ketiga dapat dilihat pada grafik di bawah ini:

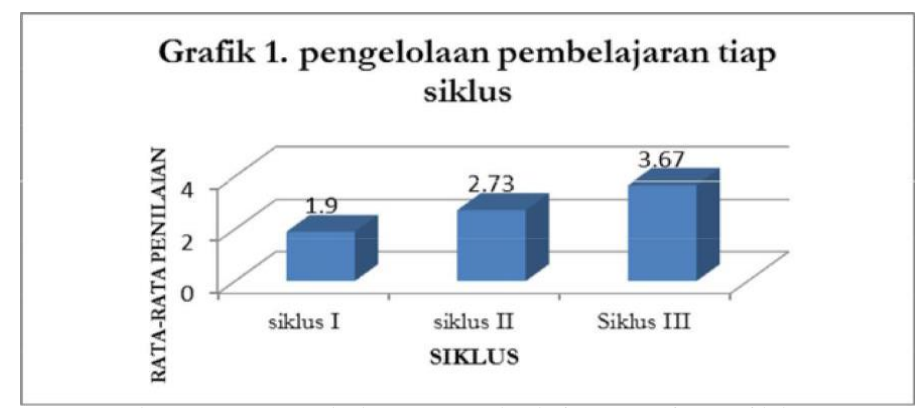

Gambar 2. Pengelolaan Pembelajaran Tiap Siklus

Berdasarkan grafik di atas dapat dijelaskan bahwa penilaian pembelajaran Speaking English tiap siklus mengalami peningkatan. Hal ini menunjukkan bahwa pengelolaan pengajaran Speaking English dengan menggunakan metode flipped classroom .yang dilakukan oleh dosen semakin baik dan untuk siklus III dosen mengelola pembelajaran dengan sangat baik seperti yang ada pada gambar grafik di atas ini. 


\section{Pembahasan}

Peningkatan Keterampilan Berbicara Bahasa Inggris Dengan Menggunakan MetodeFlipped Classroom.

\section{a. Hasil dan Analisis Penilaian Kinerja Speaking English Skill Mahasiswa}

Untuk mengetahui peningkatan keterampilan berbicara bahasa Inggris pada mahasiswa semester IV Jurusan Sastra Inggris Universitas Abdurachman Saleh, peneliti menilai kinerja Speaking English mahasiswa tersebut berdasarkan aspek yang dinilai, antara lain kelancaran (fluency), ketepatan (accuracy), kesesuaian makna (comprehension). Dari hasil dan analisis penilaian kinerja Speaking English mahasiswa selama kegiatan belajar mengajar berlangsung, dapat disimpulkan bahwa kinerja mahasiswa semakin baik pada setiap siklusnya, mulai dari siklus I sampai siklus III. Psikomotorik mahasiswa meningkat serta hasil yang dicapai akan menjadi lebih baik. Revisi ini digunakan untuk pembelajaran Speaking English selanjutnya jika dilakukan dengan metode yang sama.

\section{b. Peningkatan Keterampilan Berbicara Bahasa Inggris Dengan}

\section{Menggunakan Metode Flipped Classroom.}

a. Hasil dan Analisis Penilaian Kinerja Speaking English Skill Mahasiswa

Untuk mengetahui peningkatan keterampilan berbicara bahasa Inggris pada mahasiswa semester IV Jurusan Sastra Inggris Universitas Abdurachman Saleh, peneliti menilai kinerja Speaking English mahasiswa tersebut berdasarkan aspek yang dinilai, antara lain kelancaran (fluency), ketepatan (accuracy), kesesuaian makna (comprehension). Dari hasil dan analisis penilaian kinerja Speaking English mahasiswa selama kegiatan belajar mengajar berlangsung, dapat disimpulkan bahwa kinerja mahasiswa semakin baik pada setiap siklusnya, mulai dari siklus I sampai siklus III.

Nilai mahasiswa dalam kegiatan Speaking di kelas untuk ketepatan ( accuracy), pada siklus ke satu adalah 2.75, siklus kedua sebesar 3.31 dan siklus 
ketiga 3.92. Nilai mahasiswa untuk kelancaran berbahasa ( fluency) pada siklus ke satu adalah 2.75, siklus kedua sebesar 3.31 dan siklus ketiga 3.92, sedangkan nilai mahasiswa dalam kegiatan Speaking di kelas untuk kesesuaian makna ( comprehension), pada siklus ke satu adalah 2.41, siklus kedua sebesar 2.68 dan siklus ketiga 3.82 .

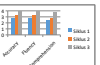

Gambar 3. Nilai Pemeringkatan Kemampuan Speaking

Dari Gambar 3 di atas, dapat dilihat bahwa persentase nilai mahasiswa yang diperoleh juga semakin meningkat pada setiap siklus.

\section{b. Analisis Hasil Belajar Speaking English Mahasiswa}

Standar ketercapaian kelas diperoleh jika terdapat 85\% mahasiswa telahmencapai standar ketercapaian kinerja mahasiswa. Dari penjelasan ini, diperoleh grafik standar ketercapaian kinerja mahasiswa pada setiap siklus adalah sebagai berikut:

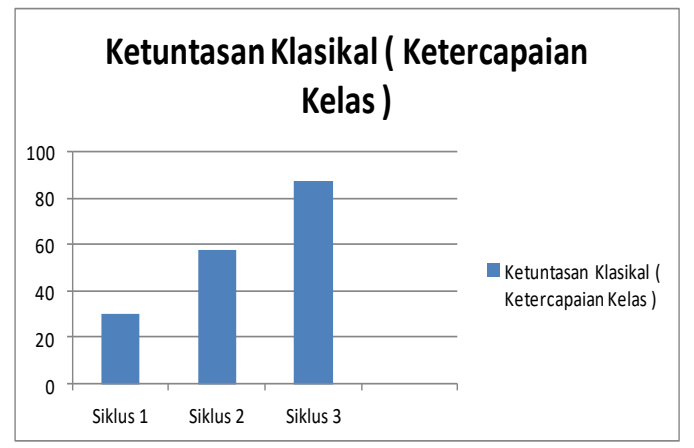

Gambar 4. Ketercapaian Kinerja Mahasiswa Setiap Siklus 
Dari evaluasi (tes Speaking English) yang diberikan kepada mahasiswa, diperoleh nilai hasil belajar Speaking English mahasiswa semester IV pada setiap siklusnya, yaitu hasil belajar Speaking English mahasiswa pada siklus I yang tidak tuntas 28 mahasiswa, untuk mahasiswa yang tuntas sebanyak 12 mahasiswa dengan persentase ketuntasan sebesar $30 \%$ dan nilai rata-rata 59,25. Untuk hasil belajar Speaking English mahasiswa pada siklus II yang tidak tuntas 23 mahasiswa, untuk mahasiswa yang tuntas sebanyak 17 mahasiswa dengan persentase ketuntasan sebesar 57,5\% dan nilai rata-rata 66,92. Sedangkan untuk hasil belajar Speaking English mahasiswa pada siklus III yang tidak tuntas 5 mahasiswa, untuk mahasiswa yang tuntas sebanyak 35 mahasiswa dengan persentase ketuntasan sebesar $87,5 \%$ dan nilai rata-rata 76,42 .

Berdasarkan hasil analisis data pengelolaan pembelajaran Speaking English yang dilakukan oleh dosen pada siklus I diperoleh catatan bahwa Mahasiswa kurang memberikan respon positif selama proses pembelajaran, banyak mahasiswa yang masih menggunakan Bahasa Indonesia dikombinasikan dengan Bahasa Inggris untuk menjelaskan tentang objek wisata. Sebagian besar mahasiswa menggunakan kata penghubung "mmm" dan "eee" apabila lupa atau tidak memahami kosakata dalam bahasa Inggris. Mahasiswa malu ketika presentasi di depan kelasMahasiswa kurang antusias, karena banyak mahasiswa yang bergurau selama pembelajaran Speaking English sehingga kondisi kelas agak ramai.. Pada siklus II menunjukkan bahwa kekurangan pada siklus I sudah berkurang, tetapi belum seluruhnya.

Pada siklus II mahasiswa masih kesulitan dalam melaksanakan presentasi. Dosen sudah lebih baik dalam menguasai kelas walaupun masih ada mahasiswa yang bergurau dan tidak serius selama pembelajaran Speaking English berlangsung di dalam kelas.

Pada siklus III kekurangan pada siklus I dan siklus II sudah teratasi. Pengelolaan pembelajaran yang baik ini ternyata relevan dengan kinerja 
mahasiswa pada saat melakukan proses pembelajaran Speaking English, dimana kinerja mahasiswa yang diperoleh semakin baik dari siklus I sampai siklus III.

Secara klasikal pada siklus I, II dan III terdapat peningkatan nilai ketuntasan belajar mahasiswa yaitu ketuntasan kelas pada masing-masing siklus sebesar $30 \%$, 57,5\% dan 87,5\%, sehingga dapat dikatakan bahwa penerapan metode flipped classroom dalam pembelajaran Speaking English dapat meningkatkan hasil belajar mahasiswa.

\section{KESIMPULAN}

Dari hasil analisis dalam penelitian dan pembahasan yang telah diperoleh melalui penerapan metode flipped classroom dalam pembelajaran berbicara bahasa Inggris pada mahasiswa semester IV Jurusan Bahasa Inggris Universitas Abdurachman Saleh, dapat disimpulkan bahwa dari data yang telah dianalisis diperoleh hasil tentang pengelolaan pengajaran yang dilakukan dosen semakin baik dari siklus I sampai siklus III. Pada siklus I skor rata-ratanya sebesar 1,90 dengan kategori cukup, pada siklus II sebesar 2,73 dengan kategori baik, dan pada siklus III sebesar 3,67 dengan kategori sangat baik. Nilai mahasiswa dalam kegiatan Speaking di kelas untuk ketepatan ( accuracy), pada siklus ke satu adalah 2.75, siklus kedua sebesar 3.31 dan siklus ketiga 3.92. Nilai mahasiswa untuk kelancaran berbahasa ( fluency) pada siklus ke satu adalah 2.75, siklus kedua sebesar 3.31 dan siklus ketiga 3.92, sedangkan nilai mahasiswa dalam kegiatan Speaking di kelas untuk kesesuaian makna ( comprehension), pada siklus ke satu adalah 2.41, siklus kedua sebesar 2.68 dan siklus ketiga 3.82.

Dari evaluasi (tes Speaking English) yang diberikan kepada mahasiswa, diperoleh nilai hasil belajar Speaking English mahasiswa semester IV pada setiap siklusnya, yaitu hasil belajar Speaking English mahasiswa pada siklus I yang tidak tuntas 28 mahasiswa, untuk mahasiswa yang tuntas sebanyak 12 mahasiswa dengan persentase ketuntasan sebesar 30\% dan nilai rata-rata 59,25. Untuk hasil belajar Speaking English mahasiswa pada siklus II yang tidak tuntas 23 mahasiswa, untuk mahasiswa yang tuntas sebanyak 17 mahasiswa dengan 
persentase ketuntasan sebesar 57,5\% dan nilai rata-rata 66,92. Sedangkan untuk hasil belajar Speaking English mahasiswa pada siklus III yang tidak tuntas 5 mahasiswa, untuk mahasiswa yang tuntas sebanyak 35 mahasiswa dengan persentase ketuntasan sebesar $87,5 \%$ dan nilai rata-rata 76,42.. Hal ini ditunjukkan dengan semakin meningkatnya persentase kemampuan berbicara mahasiswa dari siklus I sampai siklus III.

\section{SARAN}

Dari hasil penelitian ini dapat diambil hikmah untuk mensiasati kekurangan jam dalam proses pembelajaran dosen bisa menggunakan strategi flipped classroom. Hal yang perlu diperhatikan adalah dosen terlebih dahulu mempersiapkan pembelajaran secara matang sehingga bahan pembelajaran yang harus dipelajari oleh mahasiswa dirumah sudah sistematis dan tidak menimbulkan masalah. 


\section{DAFTAR PUSTAKA}

Andi Prastowo. (2012). Panduan Kreatif Membuat Bahan Ajar Inovatif. Yogyakarta: Diva Press.

Bergman, J., A. Sams. 2012. Flip Your Classroom:Reach Every Student in Every Class Every Day.United States: The International Society for Technology in Education (ISTE).

Brame, C. J. 2013. Flipping the Classroom. Nashville: Vanderbilt University. Tersedia di http://cft.vanderbilt.edu/files/Flipping-theclassroom. pdf [diakses 6-06-2017].

Forster, M. 2004. High Order Thinking Skills. Research Developments, 11(1): 16. Tersedia di http://research.acer.edu.au/resdev/vol11/is s11/1/ [diakses 6 Mei 2017].

Heereid, C.F. \& N. A. Schiller. 2013. Case Studies and the Flipped Classroom. Journal of College Science Teaching, 42(5): 62-66. http://www.nsta.org/publications/browse_j journals.aspx ?action=issue \&id=5091 [diakses 7 April 2017].

Kasbolah, K. \& Sukaryana, I.W. 2006. Penelitian Tindakan Kelas. Malang: UM Press

Knewton. 2011. Flipped Classroom: A New Method of is Turning The Traditional Classroom on Its Head. New York: Knewton. http://www.knewton.com/flippedclassroom/[diakses 7 April 2017].

Steele, K. M. 2013. The Flipped Classroom: CuttingEdge, Practical stategies to Successfully "Flip" Your Classroom. Online. Tersedia di http://www.kevinmsteele.com/ the_flipped_classroom_-_ice.pdf [diakses 1Mei 2017].

Utari, R. 2013. Taksonomi Bloom: Apa dan bagaimana Menggunakannya. Jakarta: Pusdiklat KNPK. Tersedia di http://www.bppk.depkeu.go.id/webpkn/att achments/766_1Taksonomi\%20Bloom\%20- \%20Retno-ok-mima.pdf [diakses 4 Mei 2017]. 